\title{
RESTITUTION ON A CONSOLIDATED AREA
}

Gordana Nataroš ${ }^{1}$

UDK: 332.262:347.232

Summary: In the process of restitution of confiscated property of the former owner, initiated at the request of legal successors, on the basis of case file and all evidence provided, when it comes to the fact that the procedure of land consolidation was carried out on the land parcels in question, these are the issues which require expert knowledge in the field of geodesy. At the request of the claimant, Agency for Restitution orders in the Conclusion the expertise in an administrative matter through a court expert in the field of geodesy. The expert's task is to identify, on the basis of complete files, the numbers and areas that were taken away from the former owner.

When it is determined under what numbers and which area of the identified parcels entered the consolidation mass and what is the total number of value units, the expert proposes the parcels obtained from the consolidation mass according to the principle of land consolidation. The calculation factor of the cadastral class and the coefficient of reduction for the road and canal network are taken into account. Parcels are approximated.

The entire procedure is done according to the Technical Instructions for performing geodetic-technical works in the procedure of land restitution which is an integral part of the Regulation for the implementation of the Law on the manner and conditions for the recognition of rights and the return of land transformed into social property based on the agricultural land fund and confiscation due to unfulfilled obligations from mandatory purchase of agricultural products ("Official Gazette of RS" No. 41/1991 and 4/1992).

Keywords: Restitution, Consolidation, Cadastre, Parcel, Expertise

\section{INTRODUCTION}

Restitution is the process of the return of property and indemnification for the property that was seized on the territory of the Republic of Serbia from individuals and endowments after March 9, 1945, in accordance with the regulations on agrarian reform, nationalization, sequestration, acts on nationalization and other regulations (a total of 41 regulations passed between 1945 and 1970) and transferred to the national, state, social or cooperative property.

The Restitution Directorate was established by the Law on the Return (Restitution) of Property to Churches and Religious Communities from 2006, organizationally constituted in early 2007 and finally on 01/03/2012 in accordance with Article 63, Paragraph 2 of the Law on the Return of Seized Property and Indemnification ("Official

\footnotetext{
${ }^{1}$ Gordana Nataroš, MSc in Geodesy, City Administration Zrenjanin
} 
6.

МЕЂУНАРОДНА КОНФЕРЕНЦИЈА

Савремена достигнућа у грађевинарству 20. април 2018. Суботица, СРБИЈА

Gazette of the Republic of Serbia" No. 72/2011, 108/2013, 142/2014 and 88/201 Decision of the Constitutional Court), the Agency for Restitution took over the files, work equipment, archives and the Restitution Directorate's staff.

\subsection{LEGAL MECHANISMS BY WHICH THE PROPERTY WAS SEIZED}

Applying over 40 laws and other regulations in the period from 1945 to 1968, the seizure of private property was carried out by the following legal mechanisms:

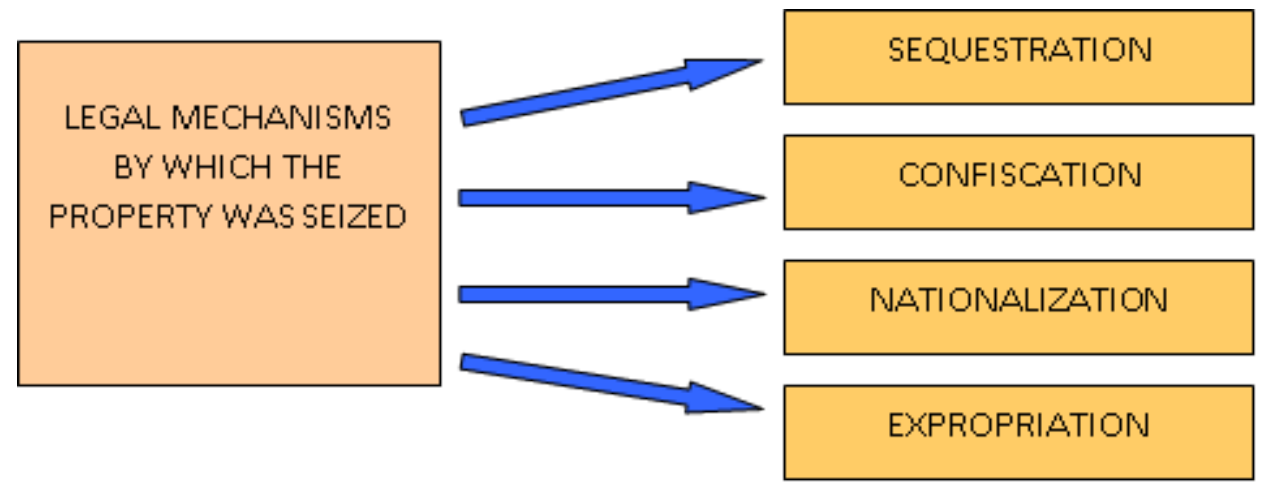

\subsubsection{Sequestration}

Sequestration as a security measure involved the temporary seizure of management over the entire property or part of a property of one or more persons for which there was a presumption that the punishment of property confiscation would be imposed upon the owner. In accordance with this measure, management of the property was transferred to the competent state body and it lasted until the finalization of the procedure regarding the acts and cases for which the sanction of confiscation of the property was envisaged.

\subsubsection{Confiscation}

Confiscation is a legal instrument by which private property is seized in favour of the state, without compensation.

The first federal Law on property confiscation was passed on 09/06/1945, and it was amended on 27/07/1946. Pursuant to the provisions of Article 1 of this Law, confiscation involves a compulsory seizure, without compensation in favour of the state, of the whole property (complete confiscation) or a certain part of the property (partial confiscation) of a natural or legal person.

\subsubsection{Nationalization}

In law, nationalization implies (on the basis of a government acts) the forcible transfer to the state property of large or commercial enterprises of a particular branch of economy, with or without compensation. Nationalization was one of the first and most radical 
Contemporary achievements in civil engineering 20. April 2018. Subotica, SERBIA

economic and political measures of all communist countries, after the takeover of power. The seized means of production and other immovable assets became a material base for the construction of socialist and communist states.

\subsubsection{Expropriation}

Expropriation as a legal mechanism means the forcible seizure of private property in the general interest, which needs to be interpreted restrictively, with just compensation that relates to the market value of the expropriated real estate.

Expropriation was carried out in favour of the state, for the needs of state bodies, institutions, enterprises, cooperatives and other organizations. All property that was not seized from owners through confiscation or nationalization practically came under the impact of expropriation and was transferred without compensation to state property.

\section{RESTITUTION ON A CONSOLIDATED AREA}

\subsection{Land consolidation}

Consolidation is a set of measures in the field of spatial planning, law, technology, economics and agriculture, which are carried out by state authorities in the land territory (outside urban areas) for the purpose of improving the conditions of life and exploitation of agricultural land.

Consolidation includes:

- merging of agricultural parcels and redistribution of ownership over them (thereby reducing their number);

- planning of agricultural production;

- design, construction and restoration of (rural) roads, irrigation systems and belts of forests;

- implementation of protective measures (protection of water, land, forests, flora and fauna, environment).

\subsection{Required documentation}

Republic Geodetic Authority, upon the request of the claimant who is in the process of restitution, issues a certificate confirming that the land consolidation was carried out on the topographic parcels, contained in the Decision on confiscated property, for the cadastral municipality. Data are not issued for them (an excerpt from the register of real estate and certificates of Republic Geodetic Authority (RGA) on identification of old and new survey).

In the process of restitution of confiscated property of the former owner, initiated at the request of legal successors, on the basis of case file and all evidence provided (RGA certificates), when it comes to the fact that the procedure of land consolidation was carried out over the parcels concerned, these are the issues that require expert knowledge in the field of geodesy. 
At the request of the claimant, Agency for Restitution orders in the Conclusion the expertise in an administrative matter through a court expert in the field of geodesy.

The expert's task is to identify, on the basis of complete files, the numbers and areas that were taken away from the former owner. For the seized arable agricultural land, all cadastral data are reduced to field crops by translating the seized orchards, vineyards, gardens, meadows and pastures into the field crops, with the class of the nearest parcel of the field.

When it is determined under what numbers and which area of the identified parcels entered the consolidation mass and what is the total number of value units, the expert proposes the parcels obtained from the consolidation mass according to the principle of land consolidation. The calculation factor of the cadastral class and the coefficient of reduction for the road and canal network are taken into account. Parcels are approximated.

The entire procedure is done according to the Technical Instructions for performing geodetic-technical works in the procedure of land restitution which is an integral part of the Regulation for the implementation of the Law on the manner and conditions for the recognition of rights and the return of land transformed into social property based on the agricultural land fund and confiscation due to mandatory purchase of agricultural products ("Official Gazette of RS" No. 41/91, 44/91, 4/92, 8/97, 103/2003).

We will show on a concrete example the procedure for identifying the seized parcels, the procedure for the proposal of allocating parcels from the consolidation mass, all according to the Technical Instructions for performing geodetic-technical works in the process of land restoration, and for the purpose of the development of expertise.

At the very beginning of the procedure of expertise, the expert adheres to the final decision made by the District National Committee, the Department of Agrarian Reform from 1946.

Pursuant to Article 3, Item 5 and Article 8 of the Law, it is seized free from encumbrance in favour of the land fund of the following area:

\begin{tabular}{|c|l|l|l|c|}
\hline $\begin{array}{c}\text { Cadastral } \\
\text { municipality }\end{array}$ & $\begin{array}{c}\text { Land registry } \\
\text { sheet }\end{array}$ & $\begin{array}{c}\text { Topographic } \\
\text { parcel }\end{array}$ & \multicolumn{1}{|c|}{ Crops } & Area \\
\hline Petrovgrad & 14759 & 4747 & Arable land & $1 \mathrm{j}^{2} 1248 \mathrm{ftm}^{2} 3$ \\
\hline & 15068 & $6618 / 6619 / \mathrm{b}$ & & $1 \mathrm{j} 1125 \mathrm{ftm}^{2}$ \\
\hline & 3281 & $6618-6619 / \mathrm{a}$ & Vineyard & $5 \mathrm{j} \quad 139 \mathrm{ftm}^{2}$ \\
\hline & 3281 & $4966 / \mathrm{a}$ & Arable land & $20 \mathrm{j} \quad 781 \mathrm{ftm}^{2}$ \\
\hline
\end{tabular}

\footnotetext{
${ }^{2} \mathrm{j}=\mathrm{a}$ unit of land area "jutro" equal to 5,754.64 $\mathrm{m}^{2}$

${ }^{3} \mathrm{ftm}^{2}=$ square fathom
} 
Contemporary achievements in civil engineering 20. April 2018. Subotica, SERBIA

\begin{tabular}{|c|c|c|c|c|c|}
\hline & 3281 & $3979 / \mathrm{a} / 2$ & Guvno $^{4}$ & & $200 \mathrm{ftm}^{2}$ \\
\hline & 3281 & $4747 / \mathrm{a}$ & Arable land & $5 \mathrm{j}$ & $543 \mathrm{ftm}^{2}$ \\
\hline & 3281 & 4007/b & Guvno & & $217 \mathrm{ftm}^{2}$ \\
\hline & 5603 & 8404/b & Arable land & & $333 \mathrm{ftm}^{2}$ \\
\hline & 9410 & $4417 / a / 3$ & Arable land & & $400 \mathrm{ftm}^{2}$ \\
\hline & 9410 & 4416/3 part & & $7 \mathrm{j}$ & $76 \mathrm{ftm}^{2}$ \\
\hline & 14758 & 4760 & Arable land & $3 \mathrm{j}$ & $32 \mathrm{ftm}^{2}$ \\
\hline & 7120 & 4419/a & Arable land & $4 j$ & \\
\hline & 5603 & $8235 / 6 / 1 / 1$ & & & $293 \mathrm{ftm}^{2}$ \\
\hline Melenci & 3227 & 5579/352 part & & $1 \mathrm{j}$ & $1329 \mathrm{ftm}^{2}$ \\
\hline Total: & & & & $51 \mathrm{j}$ & $316 \mathrm{ftm}^{2}$ \\
\hline
\end{tabular}

The table clearly presents the data of the seized land.

On the basis of the RGA certificate that confirms that land consolidation was carried out on the topographic parcels contained in the Decision on confiscated property for the cadastral municipality, the expert enters data on the parcels that were subject to land consolidation in the statement of identification. Statement of identification is formed based on photocopy of the old land registry sheets, a photocopy of the extract from the consolidation mass book fund.

\footnotetext{
${ }^{4}$ Guvno = obsolete term for a field where wheat was threshed
} 
Савремена достигнућа у грађевинарству 20. април 2018. Суботица, СРБИЈА

\subsection{Identification of parcels}

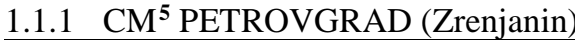
PARCELS SEIZED BASED ON DECISION FROM 1946

\begin{tabular}{|c|c|c|c|c|c|c|c|c|c|c|c|c|c|c|c|}
\hline No & $\begin{array}{l}\text { LRS }^{6} \\
\text { No }\end{array}$ & $\begin{array}{l}\text { PARCEL } \\
\text { TOPOGR } \\
\text { APHIC } \\
\text { NUMBER. }\end{array}$ & CROPS & & $\mathrm{ftm}^{2}$ & $\begin{array}{l}\text { PARCEL } \\
\text { CADAST } \\
\text { RAL } \\
\text { NUMBER }\end{array}$ & CROPS & & $\begin{array}{l}\text { ARE } \\
\text { A A }\end{array}$ & & $\begin{array}{c}\text { AS } \\
\text { SES } \\
\text { SM } \\
\text { EN } \\
\text { T }\end{array}$ & $\begin{array}{c}\text { A TOTAL } \\
\text { OF } \\
\text { VALUE } \\
\text { UNITS }\end{array}$ & $\begin{array}{r}A \\
\mathrm{RE} \\
\mathrm{TO} \\
\mathrm{C} \\
\mathrm{F}\end{array}$ & $\begin{array}{l}\text { ARE } \\
\text { DUC } \\
\text { FIR } \\
\text { LAS } \\
\text { IELI }\end{array}$ & \\
\hline 1 & 14759 & 4747 & $\begin{array}{l}\text { Arable } \\
\text { land }\end{array}$ & 1 & 1248 & $7555 / 2$ & field & 01 & 02 & 43 & 2 & $9,218.70$ & 00 & 92 & 18 \\
\hline 2 & 15068 & $\begin{array}{l}\text { 6618/6619/ } \\
\text { б }\end{array}$ & & 1 & 1125 & $\begin{array}{l}7009 / 2 \\
7010 / 2 \\
7011\end{array}$ & $\begin{array}{l}\text { field } \\
\text { field } \\
\text { ditch }\end{array}$ & $\begin{array}{l}00 \\
00\end{array}$ & $\begin{array}{l}67 \\
22\end{array}$ & $\begin{array}{l}58 \\
05\end{array}$ & $\begin{array}{l}1 \\
1\end{array}$ & $\begin{array}{l}6,758.00 \\
2,205.00 \\
0,268.00\end{array}$ & $\begin{array}{l}00 \\
00 \\
00\end{array}$ & $\begin{array}{l}67 \\
22 \\
02\end{array}$ & $\begin{array}{l}58 \\
05 \\
68\end{array}$ \\
\hline 3 & 3281 & $\begin{array}{l}\text { 6618/6619/ } \\
\text { a }\end{array}$ & Vineyard & 5 & 139 & $\begin{array}{l}7009 / 1 \\
7010 / 1\end{array}$ & $\begin{array}{l}\text { field } \\
\text { field }\end{array}$ & $\begin{array}{l}01 \\
01\end{array}$ & $\begin{array}{l}75 \\
17\end{array}$ & $\begin{array}{l}62 \\
11\end{array}$ & $\begin{array}{l}2 \\
3\end{array}$ & $\begin{array}{r}15,805.80 \\
9,251.69\end{array}$ & $\begin{array}{l}01 \\
00\end{array}$ & $\begin{array}{l}58 \\
92\end{array}$ & $\begin{array}{l}06 \\
52\end{array}$ \\
\hline 4 & 3281 & 4966/a & $\begin{array}{l}\text { Arable } \\
\text { land }\end{array}$ & 20 & 781 & $7253 / 4$ & $\begin{array}{l}\text { field } \\
\text { field }\end{array}$ & $\begin{array}{l}10 \\
01\end{array}$ & $\begin{array}{l}56 \\
22\end{array}$ & $\begin{array}{l}23 \\
79\end{array}$ & $\begin{array}{l}2 \\
3\end{array}$ & $\begin{array}{r}95,060.70 \\
9,700.41\end{array}$ & $\begin{array}{l}09 \\
00\end{array}$ & $\begin{array}{l}50 \\
97\end{array}$ & $\begin{array}{l}61 \\
00\end{array}$ \\
\hline 5 & 3281 & $4747 / \mathrm{a}$ & $\begin{array}{l}\text { Arable } \\
\text { land }\end{array}$ & 5 & 543 & 7555/1 & $\begin{array}{l}\text { field } \\
\text { field }\end{array}$ & $\begin{array}{l}01 \\
01\end{array}$ & $\begin{array}{l}22 \\
84\end{array}$ & $\begin{array}{l}79 \\
47\end{array}$ & $\begin{array}{l}3 \\
2\end{array}$ & $\begin{array}{r}9,700.41 \\
16,602.30\end{array}$ & $\begin{array}{l}00 \\
01\end{array}$ & $\begin{array}{l}97 \\
66\end{array}$ & 00 \\
\hline 6 & 9410 & $4417 / \mathrm{a} / 3$ & $\begin{array}{l}\text { Arable } \\
\text { land }\end{array}$ & - & 400 & 7819/1/a/1 & field & 00 & 28 & 77 & 2 & $2,589.30$ & 00 & 25 & 89 \\
\hline
\end{tabular}

${ }^{5} \mathrm{CM}=$ cadastral municipality

${ }^{6}$ LRS = Land registry sheet

${ }^{7} \mathrm{~A}=\mathrm{a}$ unit of land area "ar" equal to $100 \mathrm{~m}^{2}$

${ }^{8} \mathrm{~A}=$ a unit of land area "ar" equal to $100 \mathrm{~m}^{2}$

CM ZRENJANIN III PARCELS WHICH ENTERED CONSOLIDATION MASS IN 1989 \begin{tabular}{|l|c|c|c|c|c} 
PARCEL & CROPS & AREA & AS & A TOTAL & AREA \\
CADAST & & HA A M2 $^{7}$ & SES & OF & REDUCED \\
RAL & & & SM & VALUE & TO FIRST- \\
NUMBER & & & EN & UNITS & CLASS \\
& & & T & & FIELD
\end{tabular} 
Contemporary achievements in civil engineering 20. April 2018. Subotica, SERBIA

\begin{tabular}{|c|c|c|c|c|c|c|c|c|c|c|c|c|c|c|c|}
\hline 7 & 9410 & 4416/3 part & & 7 & 76 & $7819 / 1 / \mathrm{a} / 1$ & field & 04 & 31 & 60 & 2 & $38,844.30$ & 03 & 88 & 44 \\
\hline 8. & 14758 & 4760 & $\begin{array}{l}\text { Arable } \\
\text { land }\end{array}$ & $\begin{array}{l}1 \\
1\end{array}$ & $\begin{array}{l}816 \\
816\end{array}$ & $\begin{array}{l}7450 / 6 / 2 \\
7450 / 2 / a\end{array}$ & $\begin{array}{l}\text { field } \\
\text { field }\end{array}$ & $\begin{array}{l}00 \\
00\end{array}$ & $\begin{array}{l}86 \\
86\end{array}$ & $\begin{array}{l}90 \\
90\end{array}$ & 2 & $\begin{array}{l}7,821.00 \\
7,821.00\end{array}$ & $\begin{array}{l}00 \\
00\end{array}$ & $\begin{array}{l}78 \\
78\end{array}$ & $\begin{array}{l}21 \\
21\end{array}$ \\
\hline 9. & 7120 & $4419 / \mathrm{a}$ & $\begin{array}{l}\text { Arable } \\
\text { land }\end{array}$ & 4 & - & $\begin{array}{l}7817 / 2 / \mathrm{a} \\
7817 / 2 / 6\end{array}$ & $\begin{array}{l}\text { field } \\
\text { field }\end{array}$ & $\begin{array}{l}01 \\
01\end{array}$ & $\begin{array}{l}15 \\
15\end{array}$ & $\begin{array}{l}09 \\
09\end{array}$ & $\begin{array}{l}2 \\
2\end{array}$ & $\begin{array}{l}10,358.10 \\
10,358.10\end{array}$ & $\begin{array}{l}01 \\
01\end{array}$ & $\begin{array}{l}03 \\
03\end{array}$ & $\begin{array}{l}58 \\
58\end{array}$ \\
\hline \multicolumn{4}{|c|}{ Total CM Petrovgrad (Zrenjanin) } & 48 & 114 & & & 28 & 15 & 04 & & $252,362.6$ & 25 & 23 & 63 \\
\hline
\end{tabular}

CM MELENCI

\begin{tabular}{|c|c|c|c|c|c|c|c|c|c|c|c|c|c|c|}
\hline & & & & & & & & & & & & & & \\
\hline 1 & 3227 & 5579/352 & meadow & 1 & 1329 & |7711/2 & meadow & 01 & 05 & 35 & 5 & 6,321 & 63 & 21 \\
\hline & al for 1 & Melenci & & 01 & 1329 & & & 01 & 05 & 35 & & 6,321 & 63 & 21 \\
\hline
\end{tabular}

According to submitted documentation from RGA, Real estate cadaster office Zrenjanin, percentage of reduction for road and canal network in the procedure of land consolidation, based on the official document amounts to:

CM ZRENJANIN III $.1,3 \%$

CM MELENCI $2.0 \%$

Hence the expert finding reads as follows:

A total area of 28 ha $15 \mathrm{a} 04 \mathrm{~m} 2$ and with a total of 252,362.61 value units entered the consolidation mass for CM Zrenjanin III. Reduced to the first-class field, this is equal to 25ha 23a 63m2. During the process of land consolidation in CM Zrenjanin III, value units were reduced by $1,3 \%$ for the road and canal network. Therefore, the described reduction is carried out in this procedure. So, the total value units 252,362.61 are reduced by $3,280.71$ and thus reduced they amount to $249.081,90$.

A total area of 01ha $05 \mathrm{a} 35 \mathrm{~m} 2$ and with total of $6,321.00$ value units entered the consolidation mass for CM Melenci. Reduced to the first-class field, that is equal to 63a $21 \mathrm{~m} 2$. During the process of land consolidation in CM Melenci, value units were reduced by $2 \%$ for the road and canal network. Therefore, the described reduction is carried out in this procedure. So, the total value units $6,321.00$ are reduced by $0,126.42$ and thus reduced they amount to 6,194.58.

Also, for CM Melenci assessment grade 5 was taken. Because the crops of second-class meadow are equalized with the crops of the fifth-class field. The seized field is translated into the crops of the field, with the class of the nearest parcel of the field, which is the fifth-class field.

When it is determined under what numbers and which area of the identified parcels entered the consolidation mass and what is the total number of value units, the calculation factor of the cadastral class and the coefficient of reduction for the road and canal network are taken into account. The expert proposes the parcels obtained from the 
Савремена достигнућа у грађевинарству 20. април 2018. Суботица, СРБИЈА

consolidation mass according to the principle of land consolidation.. Parcels are approximated.

\subsection{Approximation of parcels}

Approximation of parcels is the conversion of the reduced area of the first cadastral class to the area of the corresponding class in the division by dividing the area reduced to the first class that is to be returned, by the calculation factor of the class in the division. The table shows the areas that are returned in different cadastral classes, compared to 1 ha of the seized area.

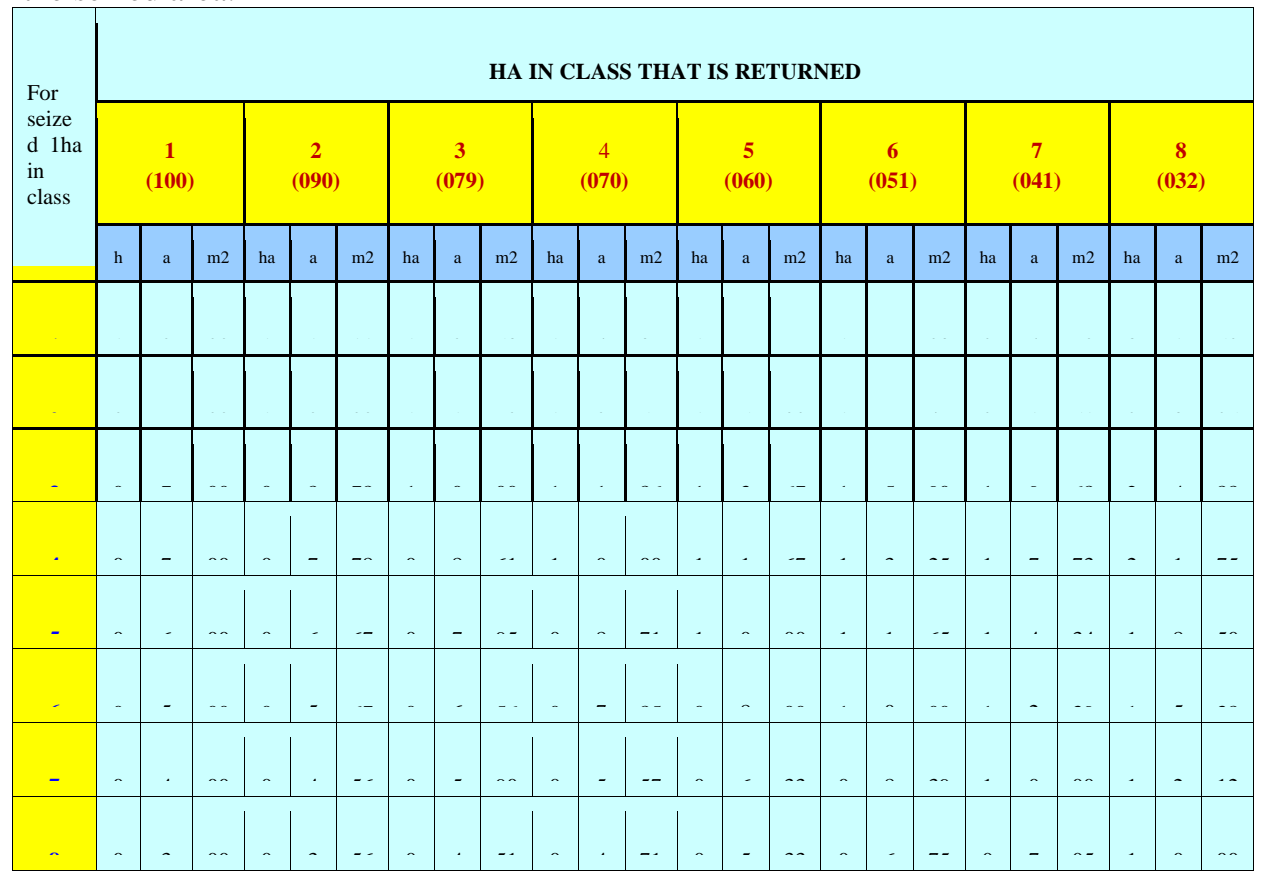

TABLE OF PROPOSED PARCELS AND AREAS FOR RETURN

\begin{tabular}{|c|c|c|c|c|c|c|c|c|c|c|}
\hline \multicolumn{11}{|c|}{ IDENTIFIED AREAS FOR RETURN } \\
\hline $\begin{array}{l}\text { PARCEL } \\
\text { NUMBER }\end{array}$ & $\begin{array}{l}\text { REF } \\
\text { No }^{9}\end{array}$ & Location & Crops & Class & $\begin{array}{c}\text { AREA FOR } \\
\text { RETURN } \\
\text { HA M2 }\end{array}$ & $\begin{array}{c}\text { Calculatio } \\
\mathrm{n} \text { factor of } \\
\text { cadastral } \\
\text { class }\end{array}$ & $\begin{array}{l}\text { Total value } \\
\text { units }\end{array}$ & \multicolumn{3}{|c|}{$\begin{array}{l}\text { The final area for } \\
\text { return from the } \\
\text { complex reduced to } \\
\text { the first-class field }\end{array}$} \\
\hline \multicolumn{11}{|c|}{ CM ZRENJANIN III } \\
\hline $3630 / 11$ & 2850 & $\begin{array}{l}\text { Prekp } \\
\text { kanala }\end{array}$ & field & 1 & 05ha50a85m2 & 1,00 & $55,085.00$ & 05ha & $50 \mathrm{a}$ & $85 \mathrm{~m} 2$ \\
\hline 1198 & 2302 & Zeldeš & $\begin{array}{l}\text { field } \\
\text { field }\end{array}$ & $\begin{array}{l}3 \\
4\end{array}$ & 09ha 42a $48 \mathrm{~m} 2$ & $\begin{array}{l}0,79 \\
0,70\end{array}$ & $\begin{array}{r}74,455.94 \\
101,259.89 \\
\end{array}$ & 17ha & $57 \mathrm{a}$ & $16 \mathrm{~m} 2$ \\
\hline
\end{tabular}

\footnotetext{
${ }^{9} \mathrm{REF}$ No $=$ real estate folio in the land registry number
} 
Contemporary achievements in civil engineering 20. April 2018. Subotica, SERBIA

\begin{tabular}{|c|c|c|c|c|c|c|c|c|c|c|}
\hline $4086 / 2$ & 2302 & $\begin{array}{l}\text { Novi } \\
\text { bunar }\end{array}$ & $\begin{array}{l}\text { field } \\
\text { field }\end{array}$ & $\begin{array}{l}4 \\
5\end{array}$ & $\begin{array}{l}\text { 01ha 69a 93m2 } \\
01 \text { ha 06a 43m2 } \\
\text { 02ha 76a 36m2 }\end{array}$ & $\begin{array}{l}0,70 \\
0,60\end{array}$ & $\begin{array}{c}11,895.49 \\
\underline{6,385.58} \\
\mathbf{1 8 , 2 8 1 . 0 7}\end{array}$ & 01ha & $82 \mathrm{a}$ & $81 \mathrm{~m} 2$ \\
\hline \multicolumn{5}{|c|}{ Total for CM Zrenjanin III } & 32ha 16a 26м2 & & $249,081.90$ & 24ha & $90 a$ & $82 \mathrm{~m} 2$ \\
\hline \multicolumn{11}{|c|}{ CM MELENCI } \\
\hline $\begin{array}{c}7334 \\
+10 \% \\
\text { increase } \\
\text { from 2. to } \\
\text { 3. class } \\
\text { Total area }\end{array}$ & 532 & Livade & field & 3 & $\begin{array}{r}01 \text { ha } 03 \mathrm{a} 4 \mathrm{~m} 2 \\
+00 \mathrm{ha} 10 \mathrm{a} 32 \mathrm{~m} 2 \\
\text { 01ha13a56m2 }\end{array}$ & 0,60 & $6,194.58$ & 00ha & $61 \mathrm{a}$ & $95 \mathrm{M} 2$ \\
\hline \multicolumn{5}{|c|}{$\begin{array}{c}\text { Total for CM Melenci } \\
\end{array}$} & 01ha13a56м2 & & $6,194.58$ & 00ha & $61 a$ & $95 \mathrm{M} 2$ \\
\hline
\end{tabular}

Based on all the above, expert gives the following: OPINION:

\subsection{Expertise}

Expert's proposal is the following allocation for in-kind return, as appropriate land from the consolidation mass to the claimants:

- In the post-consolidation parcel 3630/11 CM Zrenjanin III, location Preko kanala, first-class field of 5ha 50a $85 \mathrm{~m} 2$ area in 1/1 part (the value of 55,085.00 value units), on the parcel in public property, Republic of Serbia, so that the claimants would be owners on the parcel 3630/11 in 1/1 part or in whole. This means that the claimants would receive their property at the expense of the public property of RS. Parcel 3630/11 is registered at RGA Real estate cadaster office Zrenjanin in real estate folio in the land registry number $2850 \mathrm{CM}$ Zrenjanin III, location Preko kanala, first-class field of 5ha $50 \mathrm{a}$ of $85 \mathrm{~m} 2$ area, on which the public property of the Republic of Serbia is registered.

- In the post-consolidation parcel 1198 CM Zrenjanin III, location Zeldeš, third-class field and fourth-class field, a total area of 37ha 77a 56m2 in 238905/377756 part (the value of 175,259.82 value units), on co-owner part of the state-owned parcel of the Republic of Serbia, of the user Ministry of Agriculture, Forestry and Water Management, so that the claimants would be the owners of parcel 1198 in 238905/377756 part. Parcel 1198, is registered at RGA Real estate cadaster office Zrenjanin in real estate folio in the land registry number 2302, CM Zrenjanin III, location Zeldeš, third-class field and fourth-class field of 37ha 77a $56 \mathrm{~m} 2$ area, on which the state-owned property of the Republic of Serbia is registered, user Ministry of Agriculture, Forestry and Water Management

- In the post-consolidation parcel 4086/2 CM Zrenjanin III, location Novi bunar, fourth-class field and fifth-class field, a total area of 06ha 54a 86m2 in 27636/65486 part (the value of 18.281.07 value units), on co-owner part of the state owned parcel of the Republic of Serbia, of the user Ministry of Agriculture, Forestry and Water Management, so that the claimants would be the owners on parcel 4086/2 in 27636/65486 part. Parcel 4086/2, is registered at RGA Real estate cadaster office 
Zrenjanin in real estate folio in the land registry number 2302 CM Zrenjanin III, Novi bunar, fourth-class field and fifth-class field, of 06ha 54a $86 \mathrm{~m} 2$ area, on which stateowned property of the Republic of Serbia is registered, user Ministry of Agriculture, Forestry and Water Management.

- In the post-consolidation parcel 7334 CM Melenci, location Livade, thirdclass meadow of 04ha 19a 90m2 area in 11356/41990 part (the value of 6,194.58 value units) plus the increase of $10 \%$ when for the second-class meadow, third-class meadow is allocated on co-owner part of the state-owned parcel of the Republic of Serbia, of the user Ministry of Agriculture, Forestry and Water Management, so that the claimants would be the owners on parcel 7334 in 11356/41990 part. Parcel 7334, is registered at RGA Real estate cadaster office Zrenjanin in real estate folio in the land registry number 532 CM Melenci, location Livade, third-class meadow of 04ha 19a $90 \mathrm{~m} 2$ area, on which state-owned property of the Republic of Serbia is registered, user Ministry of Agriculture, Forestry and Water Management.

That on 18/12 2017:

In CM Zrenjanin III, location Preko kanala, Zeldeš and Novi bunar, site investigation of post-consolidation parcels 3630/11,1198 and 4086/2 was carried out, that these are arable land areas (fields), planned for leasing by public auction, which is envisaged by the Program for the Exploitation of Agricultural Land for 2018.

In CM Melenci, location Livade site investigation of post-consolidation parcel 7334 was carried out, it was found that it is a meadow, planned for leasing by public auction No. 643. as envisaged by the Program for the Exploitation of Agricultural Land for 2018.

On the above parcels there are no facilities constructed, and they can be accessed via rural roads formed in the process of land consolidation.

Parcels number 1198 and 7334 were obtained-removed from the consolidation mass in which the seized parcels entered, where parcel 3630/11 and 4086/2 in this form was obtained through subdivision, by the division from the original parcels 3630 \& 4086 .

\section{CONCLUSION}

The appointed expert is obliged to base the expertise on valid documentation and facts contained in the relevant real estate cadastre and other bodies and services, as well as direct insight into the situation on the ground. They are obliged to present their reasoned opinion impartially and in accordance with the rules of science and skill (Article 179, Paragraph 1, Administrative Procedure Act).

Often there is not enough land available for allocation on the consolidated land in the cadastral municipality, as huge complexes are located under the watering system, and are therefore leased as a pre-emptive right to lease. User Ministry of Agriculture, Forestry and Water Management, lodges an objection and challenges the return of it.

In the draft law on amendments on the restitution of confiscated property and indemnity in Article 24, Paragraph 2 is amended and reads: "If the seized agricultural land was subject to land consolidation, or merging, the consolidated land or merged land will be returned to the former owners in the territory of the cadastral municipality on which the land consolidation or merging was carried out, i.e. on the consolidated area of the neighbouring cadastral municipality where there is land for return in kind. " 
$6^{\text {th }}$

INTERNATIONAL CONFERENCE

Contemporary achievements in civil engineering 20. April 2018. Subotica, SERBIA

\section{REFERENCES}

[1] Law on Restitution of Seized Property and Indemnification ("Official Gazette of the Republic of Serbia" No. 72/2011, 108/2013, 142/2014 and 88/2015- Decision of Constitutional court)

[2] Regulation for implementing the Law on the Manner and Conditions for the Recognition of Rights and Return of Land Transformed into Social Property Based on the Agricultural Land Fund and Confiscation for Obligatory Purchase of Agricultural Products ("Official Gazette of RS" No. 41/91, 44/91 , 4/92, 8/97, 103/2003).

[3] Technical instructions for performing geodetic and technical works in the process of land restitution

[4] Gordana Nataroš, Sequestration as a temporary measure, Geodetic Department, No.120, Belgrade, 2015.

[5] Expert finding, Matić Milorad, Geodetic engineer, Restitution Agency, 2017. 